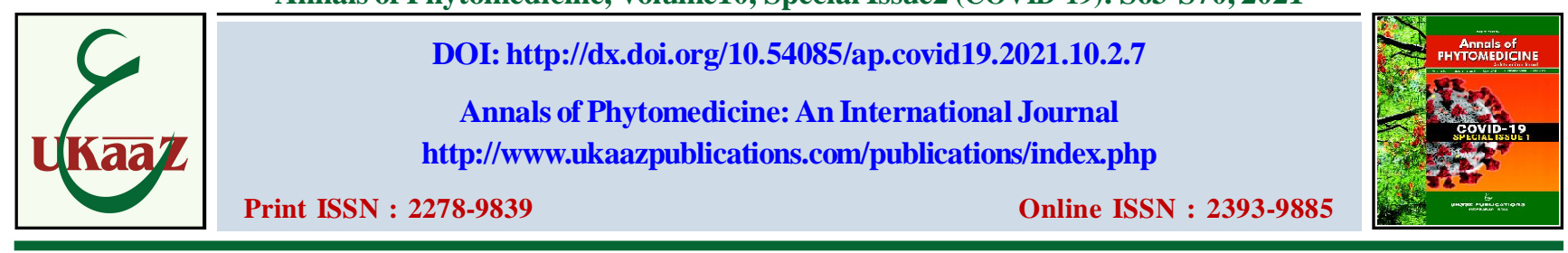

\title{
Post COVID-19 medical complications
}

\author{
Asfia Zaidi, Iffat Zareen Ahmad , Elhan Khan and Heena Tabassum* \\ Natural Products Laboratory, Integral University, Department of Bioengineering, Dasauli, Kursi Road-226026, Lucknow, Uttar Pradesh, \\ India. \\ * Dr. D.Y. Patil Biotechnology and Bioinformatics Institute, Pune-411033, Maharashtra, India
}

\begin{tabular}{|c|c|}
\hline Article Info & Abstract \\
\hline $\begin{array}{l}\text { Article history } \\
\text { Received } 1 \text { September } 2021 \\
\text { Revised } 16 \text { October } 2021 \\
\text { Accepted } 17 \text { October } 2021 \\
\text { Published Online } 30 \text { December } 2021\end{array}$ & $\begin{array}{l}\text { The infection triggered by the SARS-CoV-2 virus resulted in the novel coronavirus infection (COVID-19), } \\
\text { which was firstly identified in city of China, namely Wuhan. The main symptoms such as muscle } \\
\text { fatigability, aches, and pain are associated with this condition. Thus, a high proportion of patients who } \\
\text { recovered manifest a plethora of long-lasting symptoms. Although, many patients fully recover, } \\
\text { health complications can delay a person's complete return to a regular lifestyle. Fatigue is experienced }\end{array}$ \\
\hline $\begin{array}{l}\text { Keywords } \\
\text { Coronavirus } \\
\text { COVID-19 } \\
\text { Fatigue } \\
\text { Myalgia } \\
\text { Psychiatric } \\
\text { Anxiety }\end{array}$ & $\begin{array}{l}\text { neurological symptoms of COVID-19 are frequent and debilitating enough to have piqued the interest of } \\
\text { the scientific and general press for their brief and long effect on population health. The authors have } \\
\text { searched articles from various search engines. The articles on coronavirus have been collected from } \\
\text { PubMed and Scopus databases from Jan., } 2019 \text { to July, 2021. On the basis of their importance and } \\
\text { uniqueness, articles were included in this review. The study aims on COVID-19 infection on survivors and } \\
\text { complications to return to normal life and role of consulting sessions, physiotherapy and other } \\
\text { medications after recovery. Some long-term researches are created to investigate the COVID-19's medical, } \\
\text { psychological, and socio-economic complications. To resume normal life, COVID-19 survivors are } \\
\text { required to take aid to consultations, physiotherapy, and dermatological care. }\end{array}$ \\
\hline
\end{tabular}

\section{Introduction}

The new coronavirus disease (COVID19) was first discovered in Wuhan, China and was caused by the SARS-CoV-2 virus (Xu et al., 2020). In a review reported that the virus has infected 24,410 people within nine countries and with 938 pooled prevalence (mortality) dated on $5^{\text {th }}$ April 2020 (Grant et al., 2020). According to the WHO dashboard, dated on 24th October, 2021 reported around a total of $243,857,028$ diagnosed patients with COVID-19 infection and mortality of about $4,953,246$. The virus manifests its infection by inducing acute respiratory syndrome, accompanied by dry cough, fever, myalgia, fatigue, and dyspnea, which affects the human respiratory system (Novak, 2020).

This whole COVID-19 infection also has significant level of pessimistic impact on individual mental health and well-being around the world. The virus's transmission has been linked to widespread uneasiness among individuals worldwide, causing business disruption, economic turmoil, and public health concerns (Hyland et al., 2020; OzamizEtxebarria et al., 2020; Shigemura et al., 2020; Twenge et al., 2020). Shanbehzadeh et al. (2021) published a review of literature that examined mental and physical health issues complained by patient after the COVID-19 infection. Among patients, anxiety symptoms were most prominent $(6.5 \%-63 \%)$, followed by depressive

Corresponding author: Dr. Iffat Zareen Ahmad Professor, Natural Products Laboratory, Integral University, Department of Bioengineering, Dasauli, Kursi Road-226026, Lucknow, Uttar Pradesh, India

E-mail: iffat@iul.ac.in

Tel.: +91-9919273517

Copyright $($ ) 2021 Ukaaz Publications. All rights reserved.

Email: ukaaz@yahoo.com; Website: www.ukaazpublications.com symptoms in $4 \%$ to $31 \%$ of patients after COVID-19 infection followup. PTSD (posttraumatic stress disorder) is also a prevalent complication among patients who have been discharged from the hospital, with rates ranging from $12.1 \%$ to $46.9 \%$. The virus already has entered the acute phase of the infection, despite the fact that the impact of the COVID-19 is still unclear and uncertain. In the same study, physical health issues such as fatigue were the most prominent reported repercussion, impacting 28 per cent to 87 percent of patients and followed by the symptoms of myalgia ( $4.5 \%$ to $36 \%)$. Other symptoms observed include decreased aptitude for physical activities and impediment in daily care activities (ranging from $15 \%$ to $54 \%$ ), as well as arthralgia in patients (ranging from 6\% to 27\%) (Shanbehzadeh et al., 2021).

A significant number of individuals who recovered from the new SARs-CoV-2 experience long-term complications. Amid them, a considerable percentage of individuals $(53.1 \%)$ reported to be suffering from fatigue (Carfi et al., 2020). However, problems of the central nervous system, such as sleep difficulties, anxiety, depression, and emotional instability, are common (Behan et al., 1985). SARs Cov-2, a COVID-19 infection agent has a significant affinity for the enzyme 2 receptor (ACE2) of human angiotens in which explains the neurological manifestations by it that includes olfactory neuropathy (anosmia), brain disorders and peripheral neuropathy that are expressed in neurons and informed glial cells. According to the studies of post-mortem, viral particles were present in the neocortex neurons, cerebrospinal fluid, neocortex, hypothalamic neurons and also causes necrosis and neuronal degeneration, hyperplasia and edema of glial cells and cellular infiltrates. In a research work reported in the model of Murine has shown that the trajectory of the spreading of 
SARs-CoV-2 in the CNS is through the olfactory bulb, it has been extended to further adjoining areas and generating consequential inflammation and perivascular meningitis (Monroy-Gómez and Torres-Fernández, 2020) (Figure 1).

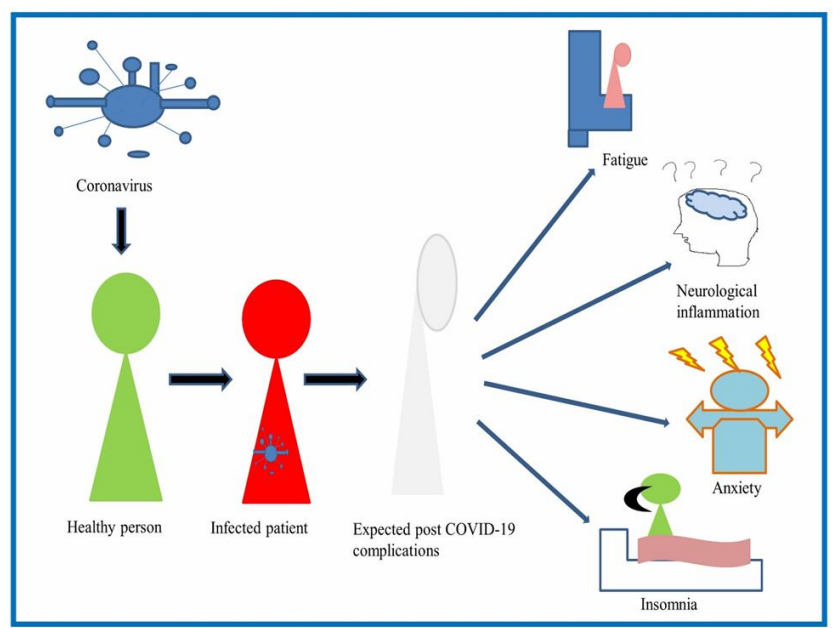

Figure 1: Post COVID-19 infection related medical complications in patients.

After COVID-19 infection, the patients with high level of inflammation in the acute phase is shown by a significant increase in the serum IL6 level. IL6 is related to excessive inflammation and is believed to have a pivot role in the COVID-19 pathogenesis (Magro, 2020). It has also been linked to peripheral and central nervous system complications, such as: stroke, headache, myelitis, GuillainBarre-like syndrome, myopathy and myositis, encephalitis, and single or multiple neuritis (Filosto et al., 2021; Koralnik and Tyler, 2020; Romero-Sánchez et al., 2020; Zhao et al., 2020).

\section{Methodology}

The authors have searched articles from various search engines. The articles on coronavirus have been collected from PubMed and Scopus databases from Jan., 2019 to July, 2021, using the key words "coronavirus", "SARS-CoV-2", "novel coronavirus", "COVID-19", or "COVID-19" in combination with "brain", "Pshychiatric symptoms", neurological", "brain fog", "behavioral therapy", "parkinsons", "myalgia", "medical consultant", "fatigue", "dysthymic", "cyclothymic", "hyperthymic", "pleocytosis", "myelopathy", "neuro-cognitive", which were modified as per the need for the search tool of each database. Articles were incorporated on the basis of significance and originality with regards to the topics covered in this review.

\section{Results}

\subsection{Post-COVID-19 symptoms}

\subsubsection{Fatigue}

A lack of energy, muscle weakness, and a fleeting sense of physical and mental weariness or exhaustion, slow response, lethargy, and inattention (Hagberg, 1981; Marcora et al., 2009; Chaudhuri and Behan, 2004) are some symptoms reported to be experienced by patients by COVID-19 and continue to develop severe "post-COVID19 syndrome", which is characterized by long-term side effects similar to myalgia encephalomyelitis (ME)/CFS symptoms (Perrin et al.,
2020). The ability of the central nervous system to maximize the activation of muscles is reduced, which depends on the spine and the mechanism on the spine, which is called "central fatigue". Thus, supraspinal fatigue is the term used to describe a decline in performance of the motor cortex as a result of chronic stress on spinal cord motor neurons (Brasil-Neto et al., 1993).

"Lack of energy" and "tiredness" are characterized as subjective feelings; thus, it is triggered by the extended periods of strenuous cognitive activity known as mental fatigue (Boksem and Tops, 2008). Between April and May 2020, twelve patients (post-COVID-19 patients) survived from the infection's acute phase (two women, 67 \pm 9.6 years of age; eleven right-handers), according to the results of the study. The study covered a number of different variables. Each patient was explicitly instructed to rate their degree of exhaustion using a digital scale to determine their overall level of fatigue (MordilloMateos et al., 2019). Due to neurological complications after SARs$\mathrm{CoV}-2$ infection, these patients are in neurological rehabilitation, Sterzing Hospital (Ortelli et al., 2021).

In one case, the author describes a patient with a possible post COVID-19 syndrome. In addition to the remaining ME/CFS cases, these possible cases post COVID-19 complications will carry out an additional burden on the health system. The specification of the mechanisms at the base of post COVID-19 syndrome is of fundamental importance, to prevent long-term/CFS followed. In the case of the report, the author proposed that the post COVID-19 fatigue syndrome can derive from damage to olfactory sensory neurons, which causes greater resistance to the flow of cerebrospinal fluid (CSF), and giving rise to congestion of the glymphatic system with an accumulation of consecutive toxic inside the central nervous system. Therefore, the neurological manifestations of COVID-19 are natural and struck to attract widespread attention of researchers and press for its brief and long-term effect on public health (Iadecola $e t$ al., 2020; Lee, 2020).

Behavioural cognitive therapy (CBT), encouraged for the syndrome associated with chronic fatigue, named as behavioural psychotherapy treatments. Face-to-face CBT, on the other hand, is a time-limited therapy that has not been deemed suitable since the epidemic owing to government constraints, since it necessitates quarantine and social restrictions. During pandemics, new digital communication technologies may provide for efficient support in the form of rehabilitation programs that incorporates intervention, prevention, education, evaluation, supervision, and consultation (Zhang and Ho, 2017; Ho et al., 2020).

\subsubsection{Psychiatric symptoms}

This pandemic is increasing more psychological problems such as insomnia, anxiety, depression, stress, anger and fear (Molodynski et al., 2021). In general, the survivors of critical disease have a significant degree of mental symptoms even after the condition recovery. Anxiety, depression, and post-traumatic stress disturbance (TPS) have been reported to be suffered and frequently reported event among the patients under these conditions (Sparks et al., 2013). Infected patients from SARs-CoV-2 had a high rate of depressive symptoms during follow-up after the acute phase of the disease (Chan et al., 2011). Being reported up to one year after the improvement of SARs-CoV-2 symptoms, these symptoms have lasted a prolonged period (Romero and Lee, 2007). The symptoms of anxiety were also reported during the follow-up of post SARs-CoV- 
2 (Cheng et al., 2004; Wu and Kanamori, 2005). A survey is reported to analyse the relationship between the symptoms of COVID-19 and depressive symptoms, anxiety and post-infection and posttraumatic symptoms between a sample of patients with diagnosis of COVID-19 mild in Brazil. Other recent results also support studies with regard to a greater probability of depressive symptoms, anxiety and post-traumatic stress between patients with COVID-19 due to factors (Giridharan et al., 2021; Motzer et al., 2021). Environmental and the psychosocial context of the pandemic is likely to cause the beginning of the symptoms post infection syndrome or greater possibility of psychiatric symptoms (Dubey et al., 2020). Therefore, the increase in symptoms psychics include an increase in suicide and behaviour design, such as brain damage, which causes increase in neurocognitive disability (Sher et al., 2021).

Stress-related symptoms (post-traumatic stress disorder, anxiety, and depression) and delirium are about a four-fold increase in the likelihood of neurocognitive disorder which in associated with mental health, and thus increasing the probability by 4.5 times (Méndez et al., 2021). Comprehensive considerations and neuropsychological factors can increase neurocognitive impairment and even mortality (Yuan et al., 2020). Therefore, there is an urgent necessity to consider mental rehabilitation for survivors after COVID-19 and take steps to strengthen protective factors such as stress to aid them with social support of the release mechanism.

\subsubsection{Neurological disorders}

The infectious agent SARs-CoV-2 from COVID-19 has a strong compatibility for the human ACE2 receptor, highly expressed in glial and neurons cells. This receptor believed to be involved in neurological manifestations like olfactory neuropathy (loss of smell), peripheral neuropathy, and brain disorders.

After Alzheimer's disease, Parkinson's disease (PD) is the most common neurodegenerative illness (Reeve et al., 2014). PD patients may be more prone to severe pneumonia because of their motor and nonmotor symptoms. In addition, the emotional impact of this epidemic, long-term immobility through social isolation and blockade, can indirectly exacerbate the motor and psychological symptoms of Parkinson's disease and lead to the devastating symptoms of the disease (Helmich and Bloem, 2020). With the exception of two case series and case reports, the clinical effects of SARs-CoV-2 infection on Parkinson's disease are largely unpredictable (Antonini et al., 2020). A community-based case-control study of twelve PD-COVID-19 cases in Italy showed that regardless of age and disease course, severe damage to motor and non-motor symptoms during mild to moderate COVID19 illness (Cilia et al., 2020). Another survey in Lombardy, Italy confirmed 105 possible COVID-19 cases, the study concluded that the risk, morbidity and mortality of patients with mild to moderate PD with COVID-19 are no different from those of the general population (Fasano et al., 2020). Many opinions and editorials have introduced the subject in addition to extensive social media and magazine coverage (Papa et al., 2020; Stoessl et al., 2020; Bhidayasiri et al., 2020; Schirinzi et al., 2020; Tipton and Wszolek, 2020).

According to a study, a person suffering from severe Parkinson's disease is also infected with acute SARs-CoV-2 virus. Perhaps, the sensitive genetic makeup of our patients makes them susceptible to neuronal oxidative stress and immune-mediated damage to mitochondria. Another possibility is that the virus induces inflammation by stimulating microglia, which leads to neurodegeneration and protein aggregation (Sadasivan et al., 2015). The short temporal delay between an acute infection and the onset of Parkinson's symptoms, on the other hand, renders this idea improbable. Other researchers have proposed the multiple hit theory, states an amalgam of destructive stress and neuroprotective suppression of responses may result in neuronal demise (Sulzer, 2007). Amazingly, during the acute infection phase, a transitory link between the commencement of SARs-CoV-2 infection and the development of Parkinson's symptoms was discovered. Prior to joining the neurology department, the patient confirmed negative for SARs-CoV-2 in real-time RT-PCR of two events; therefore, it was later found that his serum was positive for anti-SARs-CoV-2 IgG antibodies, so that the cerebrospinal fluid shows negative result for the presence of these antibodies. Nevertheless, to rule out the possibility of SARs-CoV-2 penetrating the CNS is not possible, in particular the findings about an involvement of the sense of smell and an increase in the critical number of cells. Similar to the risk factors for ADRD (advanced age, chronic cardiovascular and metabolic diseases), the following variables increase the likelihood of COVID-19 contraction and complications ( $\mathrm{Ni}$ et al., 2020). Preliminary clinical observations agree that the prevalence of ADRD-related chronic health conditions (for example, hypertension, diabetes, and cardiopulmonary disease) has increased in COVID-19 related infections and deaths. Consequently, the vast majority of verified COVID-19 cases in Detroit are middle-aged and older people who will recover from the virus once it has been identified. It is likely that they already have health issues that will raise their chance of developing ADRD in the future. Despite the fact that the danger of contracting and dying from COVID-19 is related to the issue of dementia, it has been shown that the following variables increase the likelihood of COVID-19 contraction and complications (Sadasivan et al., 2020). The severity of COVID-19 symptoms may persist in the long-term risk of dementia in the future. Secondly, the neurological symptoms of COVID-19 patients may also be caused by extreme inflammatory response to infection. According to reports, the levels of $\mathrm{IL} 1 \beta$, tumor necrosis factor $\alpha(\mathrm{TNF} \alpha)$, and interleukin 6 (IL6) are increased in the new coronavirus infection in patients of old age and ADRD. The expression of pro-inflammatory cytokines promotes oxidative stress. If not controlled, oxidative stress will degrade mitochondria, cause DNA mutations, and accelerate cell apoptosis. The net outcome is a fundamental energy failure and cell death, which leads to neurological dysfunction and, eventually, neurodegeneration (Raz et al., 2018).

\subsubsection{Myalgia}

Patients suffering from COVID-19 may have myalgia and fatigue for prolonged duration than patients with other viral infections. Myalgia (i.e., muscle pain) is another commonly informed long-term complication between individuals who have recovered from COVID19 , with $14.8 \%$ of patients suffering from long-term myalgia (WHO report).

It is pain that occurs in the jaw muscle and differs from temporomandibular joint pain in several ways. Myalgia is only related to loose mandibular function, and joint pain is a complete function of joint movement. Myalgia usually delays onset. Over time, the muscle pain caused by myalgia will continue to spread and will slowly rise and fall. Patients with temporomandibular joint pain usually point to a narrow area in front of the ear when asked about the pain point, while patients with myalgia put their hands over the entire face. In addition to the classical mechanism of myalgia known in viral fever, the mechanism of musculoskeletal pain in COVID-19 may be 
completely different (Cure and Cure, 2020a). At low cytoplasmic $p$ $\mathrm{H}$ values, COVID-19 can enter cells through the penetration of ACE2 and cause lung system infection as this receptor are also present in the brain tissue, kidneys, and musculoskeletal system, these organs are also at risk (Perico et al., 2020; Echeverría-Rodríguez et al., 2020). In a recent article, it was reported that excessive cell damage during COVID-19 infection can lead to elevated lactic acid levels, leading to hyperlactatemia (Cure and Cure, 2020b). Due to hyperlactatemia, red blood cells lose the ability to deliver oxygen to

Table 1: Post COVID-19 medical complications the tissues, so the tissues remain hypoxic. The exact mechanism of post-viral myalgia infection is unclear. Central sensitization and hypersensitivity to pain have been identified as the main pathophysiological causes of myalgia and CFS (Mohabbat et al., 2020; Nijs et al., 2016). Some studies have discussed whether SARs-CoV2 can affect skeletal muscle cells by combining with ACE2 alone or with other pro-inflammatory cytokines, resulting in cell damage and expression of growth factors, and overstimulating the dorsal root ganglia.

\begin{tabular}{|c|c|c|c|}
\hline Author & Test & Participants & Symptoms/treatment \\
\hline $\begin{array}{l}\text { In Rome, Italy, the } \\
\text { Fondazione Policlinico } \\
\text { Universitario Agostino } \\
\text { Gemelli IRCCS created a } \\
\text { post-acute outpatient } \\
\text { programme for people who } \\
\text { were discharged from the } \\
\text { hospital after recovering } \\
\text { from COVID-19. }\end{array}$ & $\begin{array}{l}\text { For SARSCoV-2, a RT-PCR } \\
\text { has been utilized. }\end{array}$ & $\begin{array}{l}143 \text { patients were included } \\
\text { with mean age of } 56.5 \text { years. } \\
\text { Out of which, } 53 \text { were women. }\end{array}$ & $\begin{array}{l}\text { At least one symptom persisted } \\
\text { in } 87.4 \% \text { of people, with tiredness } \\
\text { and dyspnea being the most } \\
\text { prominent (Saloner et al., 2020). }\end{array}$ \\
\hline $\begin{array}{l}\text { It was conducted at review } \\
\text { clinic of post-COVID-19 } \\
\text { at St James's Hospital (SJH), } \\
\text { Dublin, Ireland, for the } \\
\text { purpose of this research. }\end{array}$ & $\begin{array}{l}\text { All people who were tested } \\
\text { SARS-CoV-2 positive by } \\
\text { nasopharyngeal swab PCR } \\
\text { should be scheduled for an } \\
\text { appointment. The Chalder } \\
\text { Fatigue Scale (CFQ-11), which } \\
\text { has been validated, was used to } \\
\text { evaluate fatigue. The levels of } \\
\text { IL- } 6 \text { and sCD25 in serum were } \\
\text { determined using an ELISA. }\end{array}$ & $\begin{array}{l}\text { Outpatient appointment was } \\
\text { at tended by } 128 \text { patients } \\
\text { with } 53.9 \% \text { female and mean } \\
\text { age about } 49.5 \pm 15 \text { years. }\end{array}$ & $\begin{array}{l}\text { More than half of the patient cohort } \\
\text { reported extreme exhaustion. } 49 \% \text { of } \\
\text { the hospitalised group received } \\
\text { hydroxychloroquine, with } 8.5 \% \text { of } \\
\text { them receiving prednisolone in } \\
\text { addition to the medication } \\
\text { (Townsend } \text { et al., 2020). }\end{array}$ \\
\hline $\begin{array}{l}\text { A study by Zhang and his } \\
\text { colleagues. }\end{array}$ & $\begin{array}{l}\text { Nucleic acid testing was carried } \\
\text { out using the RT-PCR method. }\end{array}$ & $\begin{array}{l}\text { Total } 140 \text { number COVID- } 19 \\
\text { patients admitted to the } \\
\text { hospital. The median age in } \\
\text { this group was } 57 \text { years with } \\
\text { male to female ratio was } 1: 1\end{array}$ & $\begin{array}{l}\text { Coughing, fever, and tiredness were } \\
\text { the most frequent signs and symptoms } \\
\text { (Zhang et al., 2020b). }\end{array}$ \\
\hline $\begin{array}{l}\text { The Istituto per la Ricercae } \\
\text { l'InnovazioneBiomedica } \\
\text { (IRIB) of the Consiglio } \\
\text { NazionaledelleRicerche } \\
\text { (CNR) is located in } 90146 \\
\text { Palermo, Italy. }\end{array}$ & PCR test, antibody test, and CT. & $\begin{array}{l}\text { A } 56 \text {-year-old guy presented } \\
\text { himself to the hospital with } \\
\text { a chest pain. }\end{array}$ & $\begin{array}{l}\text { Symptoms included fever and dysprea. } \\
\text { In addition, the patient had trouble } \\
\text { walking, weakness in the lower limbs, } \\
\text { and cutaneous hyperalgesia, particularly } \\
\text { on the rear. As a result, the patient } \\
\text { had persistent tiredness, headaches, } \\
\text { finger paresthesia, panic episodes, } \\
\text { and severe pain (Nuzzo et al., 2021). }\end{array}$ \\
\hline $\begin{array}{l}\text { Oxford University Press } \\
\text { granted Dr. Novak royalties. }\end{array}$ & $\begin{array}{l}\text { There were standardised tests of } \\
\text { autonomic function performed } \\
\text { on her (such as the Valsalva } \\
\text { manoeuvre, deep breathing, } \\
\text { tilt and sudomotor test) and a } \\
\text { transcranial Doppler was used } \\
\text { to determine cerebral blood } \\
\text { flow velocity (CBFv). }\end{array}$ & A 64-year-old woman. & $\begin{array}{l}\text { Three months later, she was experien- } \\
\text { cing headaches, various pain syndromes } \\
\text { mood lability, incapacitating tiredness, } \\
\text { and congnitive fog. She was self- } \\
\text { quarantined for five days with } \\
\text { hydroxychloroquine and azithromycin. } \\
\text { Her fever and respiratory problems } \\
\text { were resolved after one week of } \\
\text { treatment (Novak, 2020). }\end{array}$ \\
\hline $\begin{array}{l}\text { Betul Borku and his team are } \\
\text { from the Department of } \\
\text { Internal Medicine at Biruni } \\
\text { University's Medical Faculty } \\
\text { in Istanbul, Turkey. }\end{array}$ & $\begin{array}{l}\text { A chest computed tomography } \\
\text { (CT) scan was taken. }\end{array}$ & $\begin{array}{l}60 \text {-year-old male patient was } \\
\text { admitted. }\end{array}$ & $\begin{array}{l}\text { Tiny ground-glass nodules were disco- } \\
\text { covered, indicating that the patient } \\
\text { had viral pneumonia that had spread } \\
\text { across both lungs on the image } \\
\text { (Bag Soytas et al., 2021). }\end{array}$ \\
\hline
\end{tabular}




\subsubsection{Pulmonary fibrosis}

There are many types of diffuse parenchymal lung disorders that fall under the umbrella term of interstitial lung disease (ILD), each with its own set of radiologic, clinical, and pathologic features. A recurrent characteristic is the presence of inflammation and/or fibrosis in conjunction with other symptoms. Idiopathic or chronic inflammation, genetically driven, and age-associated process of fibroproliferative may both cause pulmonary fibrosis (KalchiemDekel et al., 2018) and is also reported that its progression is associated with post-acute respiratory distress syndrome (ARDS). Despite this, persisting abnormalities in radiological following ARDS are of minimal clinical significance and have diminished as a result of protective lung ventilation (Burnham et al., 2014). In COVID-19 patients, ARDS resulting in respiratory failure is a chronic source of morbidity and death, and it is often the reason they need support of the medical ventilator (Wu et al., 2020; Chand et al., 2020).

Infection of coronavirus-19 causes ARDS in $40 \%$ of patients, with $20 \%$ of ARDS cases being life-threatening. It will take time to become apparent for the ubiquity fibrosis reported in COVID-19 patients, but initial assessment of discharged patients tends to suggest that fibrotic abnormalities occur in more than a third of recovered individuals. A pathological characteristic of ARDS, DAD (Diffuse alveolar damage) is categorized by preliminary acute inflammation in membranes of hyaline at exudative phase, preceded by phase of organising and a fibrotic stage (Liu et al., 2020). Currently, there are no FDA-approved treatments for COVID-19 pulmonary fibrosis that have been thoroughly studied and proven effective. A multitude of distinct therapeutic methods are being investigated. Long-term usage of antifibrotic, anti-inflammatory and antiviral medications has been recommended to minimize the probability of lung fibrosis advancement. In order to ascertain the risk-benefit ratio prior to medication, it is recommended that survivors get a prolonged lowdose corticosteroid which is believe to be responsible in preventing lung remodelling (Gentile et al., 2020). In addition to having antifibrotic properties, anti-fibrotic medicines include nintedanib and pirfenidone also have anti-inflammatory properties, and as a result, utilized against pneumonia in the acute phase caused by the infection (Collins and Raghu, 2019).

\subsection{Medical consultations}

Recent data indicate that $>50 \%$ of admitted patients and $10 \%$ of COVID-19 infected patients have experienced musculoskeletal and neurological disorders (Greenhalgh et al., 2020) that require rehabilitation support (Table 1). Breathing rehabilitation exercises and control of diaphragmatic breathing have been carried out, as well as work related to inhalation and exhalation time. Aerobic exercise includes cycling at sub-maximum intensity and monitoring important variables. Finally, the patient received a personalized selfrehabilitation course, and it is fully recommended to use certain workbooks for these exercises after discharge from the hospital (Piquet et al., 2021). The medical consultations availed post COVID19 infection has been summarized in Figure 2.

Patients with COVID-19 may be treated with antiviral medications (ritonavir, remdesivir, and interferon), and immunomodulators (chloroquine, mycophenolic acid, and cyclosporine) and systemic antibiotics. Many of these drugs are known to induce general skin rashes, so the differential diagnosis of general skin rashes is essential for the proper and timely treatment of these COVID-19 patients, especially in the case of fever and critical illness (Lee, 2020).

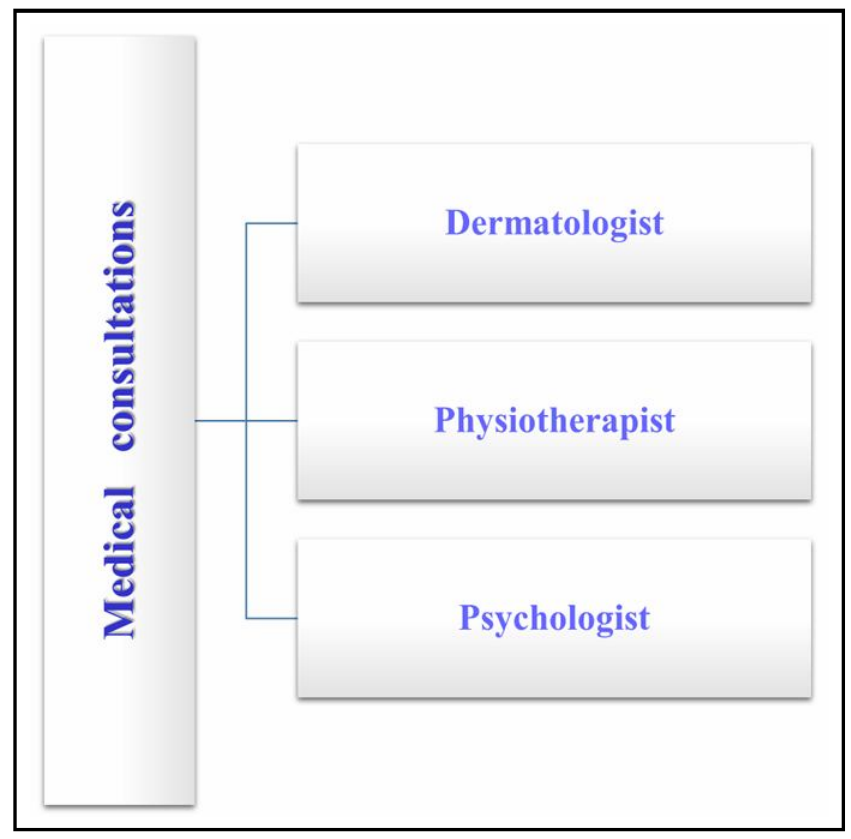

Figure 2: Medical consultations availed during COVID-19.

Although, physical symptoms can last up to 3 months in the acute phase of COVID-19, there is currently a lack of reports on the longterm psychological response of patients cured from COVID-19 (Mardani, 2020). It consists of five subtypes, namely; depression (dysthymia), cyclicality, irritability, and anxiety, and is important in determining the individual's response to environmental challenges (Akiskal et al., 2005). Emotional temperaments may affect the emotional regulation mechanism, especially cyclic temperament, which is related to emotional disorders (Pisano et al., 2020).

\section{Discussion}

The novel coronavirus disease (COVID-19) was first reported in Wuhan in December 2019. A large number of patients who have improved from coronavirus disease 2019 (COVID-19) are due to "Severe Acute Respiratory Syndrome Coronavirus 2" (SARS-CoV2) and have a large number of long-term symptoms. Therefore, due to lack of energy and prolonged cognitive activity, fatigue is considered to be one of the most important and common symptoms after COVID19. Patients admitted to the Neurorehabilitation Department of Sterzing Hospital (Vipiteno Sterzing, BZ, Italy) underwent an assessment and concluded that the multidimensional FSS (Fatigue Severity Scale) is a rough and vague assessment of daily life fatigue. In order to measure the EDDX effort immediately post physical exercise, the CR100 was adopted. FRS (Fatigue Rating Scale) finally realized the quantification of patients' perceived fatigue during clinical evaluation, and established a common denominator in these tools (Ortelli et al., 2021).

The incidence of depressive symptoms reported by patients after infection is high, such as anxiety, stress, depression, and anger due to environmental factors. Therefore, the increase in psychiatric symptoms includes an increase in suicidal thoughts and behaviour, such as damage to the brain, i.e., an increase in neurocognitive impairment. It is, therefore, recommended to arrange counselling sessions and rehabilitation centres for COVID-19 survivors ( $\mathrm{Ng}$ et al., 2018). 
There have been several risk factors for the contraction of COVID-19 and complications similar to those of ADDD (dementia relating to Alzheimer's disease), higher levels of interleukin 6 (IL6), IL11 and the tumor necrosis factor (TNF) are reported). According to a case, there is the possibility that SARS-COV-2 enters the SNC, in particular with a view to the olfactory participation and pleocytess border. However, the short period of rest between acute infection and the symptoms of Parkinsonian makes this presuppose doubtful. During the COVID-19 infection, the increase in infection in lactation levels causes cell damage, which causes hyperlactatemia. In hyperlactatemia, fabric remains hypoxic due to loss of oxygenizing capacity from erythrocytes, so that it gives rise to myalgia (Paniz-Mondolfi et al., 2020).

\section{Conclusion}

It is too early at this stage of the COVID-19 to anticipate what longterm complications are and how they should appear in the survivors of the disease in post-recovery years. Hence, the uncertainty that the human body creates in the forecast of long-term complications is due to the complexity of COVID-19 behaviour and to the variety of their goals. Therefore, several continuous studies are established to examine the physical, psychological and socio-economic consequences of the COVID-19. Therefore, control and treatment in the initial phase are not yet known. Therefore, the survivors of COVID-19 are required to receive consulting sessions, physiotherapy and dermatological aid to return to normal life.

\section{Contributors}

IZA and AZ devised the idea for this Rapid Review. AZ, IZA, EK and HT contributed to the literature search. IZA and AZ designed and drafted the Figures. AZ, IZA, EK and HT prepared the initial manuscript draft. All authors contributed to, reviewed, and approved the final draft of the paper.

\section{Acknowledgments}

The author acknowledges the Office of Doctoral Studies and Research for critically reviewing the manuscript and providing the manuscript number (IU/R\&D/2021-MCN0001249).

\section{Conflicts of interest}

The authors declare no conflicts of interest relevant to this article.

\section{References}

Akiskal, H.S.; Akiskal, K.; Allilaire, J.F.; Azorin, J.M.; Bourgeois, M.L.; Sechter, D.; Fraud, J.P.; Chatenêt-Duchêne, L.; Lancrenon, S.; Perugi, G. and Hantouche, E.G. (2005). Validating affective temperaments in their subaffective and socially positive attributes: Psychometric, clinical and familial data from a French national study. J. Affect. Disord., 85(1-2):29-36.

Antonini, A.; Leta, V.; Teo, J. and Chaudhuri, K.R. (2020). Outcome of Parkinson's disease patients affected by COVID-19. Mov. Disord., 35(6):905-908.

Bag Soytas, R.; Cengiz, M.; Islamoglu, M.S.; Uysal, B.B.; Ikitimur, H.; Yavuzer, H. and Yavuzer, S. (2021). Does the COVID-19 seroconversion in older adults resemble the young? J. Med. Virol., 93(10):5777-5782.

Behan, P.O.; Behan, W.M. and Bell, E.J. (1985). The postviral fatigue syndrome: An analysis of the findings in 50 cases. J. Infect., 10(3):211-22.
Bhidayasiri, R.; Virameteekul, S.; Kim, J.M.; Pal, P.K. and Chung, S.J. (2020). COVID-19: An early review of its global impact and considerations for Parkinson's disease patient care. J. Mov. Disord., 13(2):105114.

Bianchetti, A.; Rozzini, R.; Guerini, F.; Boffelli, S.; Ranieri, P.; Minelli, G.; Bianchetti, L. and Trabucchi, M. (2020). Clinical presentation of COVID-19 in dementia patients. J. Nutr. Health Ageing, 24(6):560-562.

Boksem, M.A. and Tops, M. (2008). Mental fatigue: Costs and benefits. Brain Res. Rev., 59(1):125-139.

Brasil Neto, J.P.; Pascual Leone, A.; Valls-Solé, J.; Cammarota, A.; Cohen, L.G. and Hallett, M. (1993). Postexercise depression of motor evoked potentials: A measure of central nervous system fatigue. Exp. Brain Res., 93(1):181-184.

Burnham, E.L.; Janssen, W.J.; Riches, D.W.; Moss, M. and Downey, G.P. (2014). The fibroproliferative response in acute respiratory distress syndrome: Mechanisms and clinical significance. Eur. Respir. J., 43:276-285.

Carfî, A.; Bernabei, R. and Landi, F. (2020). Persistent symptoms in patients after acute COVID-19. JAMA., 324(6):603-605.

Chan, Y.S.; Cheng, L.N.; Wu, J.H.; Chan, E.; Kwan, Y.W.; Lee, S.M.Y.; Leung, G.P.H.; Yu, P.H.F. and Chan, S.W. (2011). A review of the pharmacological effects of arctiumlappa (burdock). Inflammopharmacology, 19(5):245-254.

Chand, S.; Kapoor, S.; Orsi, D.; Fazzari, M.J.; Tanner, T.G.; Umeh, G.C. and Islam, M.; (2020). Dicpinigaitis, P.V. COVID-19: Associated critical illnessreport of the first 300 patients admitted to intensive care units at a New York City Medical Center. J. Intensive Care Med., 35:963970 .

Chaudhuri, A. and Behan, P.o. (2004). Fatigue in neurological disorders. Lancet., 363(9413):978-988.

Cheng, J.C.; Yoo, C.B.; Weisenberger, D.J.; Chuang, J.; Wozniak, C.; Liang, G.; Marquez, V.E.; Greer, S.; Orntoft, T.F.; Thykjaer, T. and Jones, P.A. (2004). Preferential response of cancer cells to zebularine. Cancer Cell, 6(2): 151-158.

Cilia, R.; Bonvegna, S.; Straccia, G.; Andreasi, N.G.; Elia, A.E.; Romito, L.M.; Devigili, G.; Cereda, E. and Eleopra, R. (2020). Effects of COVID-19 on Parkinson's disease clinical features: A community based case control study. Mov. Disord., 35(8):1287-1292.

Collins, B.F. and Raghu, G. (2019). Antifibrotic therapy for fibrotic lung disease beyond idiopathic pulmonary fibrosis. Eur. Respir. Rev., 28: $190-222$

Cure, E. and Cure, M.C. (2020). Angiotensin-converting enzyme inhibitors and angiotensin receptor blockers may be harmful in patients with diabetes during COVID-19 pandemic. Diabetes Metab Syndr.,14(4):349-350.

Cure, E. and Cure, M.C. (2020). Can dapagliflozin have a protective effect against COVID-19 infection? A hypothesis. Diabetes MetabSyndr., 14(4):405-406.

Dubey, S.; Biswas, P.; Ghosh, R.; Chatterjee, S.; Dubey, M.J.; Chatterjee, S.; Lahiri, D. and Lavie, C.J. (2020). Psychosocial impact of COVID-19. Diabetes Metab. Syndr., 14(5):779-788.

Echeverría-Rodríguez, O.; Gallardo-Ortíz, I.A.; Del Valle-Mondragón, L. and Villalobos-Molina, R. (2020). Angiotensin (1-7) participates in enhanced skeletal muscle insulin sensitivity after a bout of exercise. J. Endocr. Soc., 4(2):7-10.

Fasano, A.; Cereda, E.; Barichella, M.; Cassani, E.; Ferri, V.; Zecchinelli, A.L. and Pezzoli, G. (2020). COVID-19 in Parkinson's Disease Patients Living in Lombardy, Italy. Mov. Disord., 35(7):1089-1093. 
Filosto, M.; Piccinelli, S.C.; Gazzina, S.; Foresti, C.; Frigeni, B.; Servalli, M.C.; Sessa, M.; Cosentino, G.; Marchioni, E.; Ravaglia, S. and Briani, C. (2021) Guillain-Barré syndrome and COVID-19: An observational multicentre study from two Italian hotspot regions. J. Neurol. Neurosurg. Psychiatry., 92(7):751-756.

Gentile, F.; Aimo, A.; Forfori, F.; Catapano, G.; Clemente, A.; Cademartiri, F.; Emdin, M. and Giannoni, A. (2020). COVID-19 and risk of pulmonary fibrosis: The importance of planning ahead. Eur. J. Prev. Cardiol., 27(13): 1442-1446.

Giridharan, V.V.; Generoso, J.S.; Collodel,A.; Dominguini, D.; Faller, C.J.; Tardin, F.; Bhatti, G.S.; Petronilho, F.; Dal-Pizzol, F. and Barichello, T. (2021). Receptor for advanced glycation end products (RAGE) mediates cognitive impairment triggered by Pneumococcal meningitis. Neurother. J. Am. Soc. Exp. Neurother., 18(1):640-653.

Grant, M.C.; Geoghegan, L.; Arbyn, M.; Mohammed, Z.; McGuinness, L.; Clarke, E.L. and Wade, R.G. (2020). The prevalence of symptoms in 24,410 adults infected by the novel coronavirus (SARS-CoV-2; COVID-19): A systematic review and meta-analysis of 148 studies from 9 countries. PLoS One., 15(6):0234765.

Greenhalgh, T.; Knight, M.; Buxton, M. and Husain, L. (2020). Management of post: Acute COVID-19 in primary care. BMJ., 370:30-26.

Hagberg, M.A.T.S. (1981). Muscular endurance and surface electromyogram in isometric and dynamic exercise. J. Appl. Physiol., 51(1):1-7.

Helmich, R.C. and Bloem, B.R. (2020). The impact of the COVID-19 pandemic on Parkinson's disease: Hidden sorrows and emerging opportunities. J. Parkinsons Dis., 10(2):351-354.

Ho, C.S.; Chee, C.Y. and Ho, R.C. (2020). Mental health strategies to combat the psychological impact of COVID-19 beyond paranoia and panic. Ann. Acad. Med. Singap., 49(3):155-160.

Hyland, P.; Shevlin, M.; McBride, O.; Murphy, J.; Karatzias, T.; Bentall, R.P.; Martinez, A. and Vallières, F. (2020). Anxiety and depression in the Republic of Ireland during the COVID-19 pandemic. Acta. Psychiatr. Scand., 142(3):249-256.

Iadecola, C.; Anrather, J. and Kamel, H. (2020). Effects of COVID-19 on the nervous system. Cell, 183(1):16-27.

Kalchiem-Dekel, O.; Galvin, J.R.; Burke, A.P.; Atamas, S.P. and Todd, N.W. (2018) Interstitial lung disease and pulmonary fibrosis: A practical approach for general medicine physicians with focus on the medical history. J. Clin. Med., 7:476.

Koralnik, I.J. and Tyler, K.L., (2020). COVID-19: A global threat to the nervous system. Ann. Neurol., 88(1):1-11.

Lee, C.H. (2020). Role of dermatologists in the uprising of the novel corona virus (COVID-19): Perspectives and opportunities. Dermatologica Sin., 38(1):1-2

Liu, X.; Zhou, H. and Zhou Y. (2020). Risk factors associated with disease severity and length of hospital stay in COVID-19 patients. J. Infect., 81(1):95-97.

Magro, G. (2020). SARS-CoV-2 and COVID-19: Is interleukin-6 (IL-6) the 'culprit lesion' of ARDS onset? What is there besides Tocilizumab? SGP130Fc. Cytokine. X., 2(2):100-129.

Marcora, S.M., Staiano, W. and Manning, V. (2009). Mental fatigue impairs physical performance in humans. J. Appl. Physiol., 106(3):857864

Mardani, M. (2020). Post COVID-19 syndrome. Arch. Clin. Infect. Dis., 15(2): 108-819.
Mendez, R.; Balanzá Martínez, V; Luperdi, S.C.; Estrada, I.; Latorre, A.; González Jiménez, P.; Feced, L.; Bouzas, L.; Yepez, K.; Ferrando, A. and Hervas, D. (2021). Short term neuropsychiatric outcomes and quality of life in COVID-19 survivors. J. Intern. Med., 290(3):621-631.

Mohabbat, A.B.; Mohabbat, N.M.L. and Wight, E.C. (2020). Fibromyalgia and chronic fatigue syndrome in the age of COVID-19. Mayo. Clin. Proceedings Innov. Qual. Outcomes, 4(6):764-766.

Molodynski,A.; Lewis, T.; Kadhum, M.; Farrell, S.M.; LemtiriChelieh, M.; Falcão De Almeida, T.; Masri, R.; Kar, A.; Volpe, U.; Moir, F.; Torales, J.; CastaldelliMaia, J.M.; Chau, S.W.H.; Wilkes, C. and Bhugra, D. (2021). Cultural variations in wellbeing, burnout and substance use amongst medical students in twelve countries. Int. Rev. Psychiatry., 33(1):37-42.

Monroy-Gómez, J. and Torres-Fernández, O. (2020). Effects of the severe acute respiratory syndrome coronavirus (SARS-CoV) and the Middle East respiratory syndrome coronavirus (MERS-CoV) on the nervous system. What can we expect from SARS-CoV-2? Biomed. Biochim. Acta., 40:173-179.

Mordillo Mateos, L.; Soto Leon, V.; Torres Pareja, M.; Peinado Palomino, D.; Mendoza Laiz, N.; Alonso Bonilla, C.; Dileone, M.; Rotondi, M.; Aguilar, J. and Oliviero, A. (2019). Fatigue in multiple sclerosis: General and perceived fatigue does not depend on corticospinal tract dysfunction. Front. Neurol., 10:339-345.

Motzer, R.; Alekseev, B.; Rha, S.Y.; Porta, C.; Eto, M.; Powles, T.; Grünwald, V.; Hutson, T.E.; Kopyltsov, E.; Méndez-Vidal, M.J. and Kozlov, V. (2021). Lenvatinib plus pembrolizumab or everolimus for advanced renal cell carcinoma. N. Engl. J. Med., 384(14):1289-1300.

Ng, A.; Tam, W.W.; Zhang, M.W.; Ho, C.S.; Husain, S.F.; McIntyre, R.S. and Ho, R.C. (2018). IL-1 $\beta$, IL-6, TNF- $\alpha$ and CRP in elderly patients with depression or Alzheimer's disease: Systematic review and metaanalysis. Sci. Rep., 8(1):12050.

Ni, L.; Ye, F.; Cheng, M.L.; Feng, Y.; Deng, Y.Q.; Zhao, H.; Wei, P.; Ge, J.; Gou, M.; Li, X. and Sun, L. (2020). Detection of SARS-CoV-2-specific humoral and cellular immunity in COVID-19 convalescent individuals. Immunity., 52(6):971-977.

Nijs, J.; Leysen, L.; Adriaenssens, N.; Aguilar Ferrándiz, M.E.; Devoogdt, N.; Tassenoy, A.; Ickmans, K.; Goubert, D.; van Wilgen, C.P.; Wijma, A.J.; Kuppens, K.; Hoelen, W.; Hoelen, A.; Moloney, N. and Meeus, M. (2016). Pain following cancer treatment: Guidelines for the clinical classification of predominant neuropathic, nociceptive and central sensitization pain. Acta. Oncol., 55(6):659-663.

Novak, P. (2020). Post COVID-19 syndrome associated with orthostatic cerebral hypoperfusion syndrome, small fiber neuropathy and benefit of immunotherapy: A case report. Neurological Sci., 21:100-276.

Nuzzo, D.; Cambula, G.; Bacile, I.; Rizzo, M.; Galia, M.; Mangiapane, P.; Picone, P.; Giacomazza, D. and Scalisi, L. (2021). Long-term brain disorders in post COVID-19 Neurological Syndrome (PCNS) Patient. Brain Sci., 11(4):454.

Ortelli, P.; Ferrazzoli, D.; Sebastianelli, L.; Engl, M.; Romanello, R.; Nardone, R.; Bonini, I.; Koch, G.; Saltuari, L.; Quartarone, A. and Oliviero, A. (2021). Neuropsychological and neurophysiological correlates of fatigue in post-acute patients with neurological manifestations of COVID-19: Insights into a challenging symptom. J. Neurol. Sci., 420:117-271.

Ozamiz-Etxebarria, N.; Dosil-Santamaria, M.; Picaza-Gorrochategui, M. and Idoiaga-Mondragon, N. (2020). Stress, anxiety, and depression levels in the initial stage of the COVID-19 outbreak in a population sample in the northern Spain. Cad. Saude Publica., 36(4): e00054020

Paniz Mondolfi, A.; Bryce, C.; Grimes, Z.; Gordon, R.E.; Reidy, J.; Lednicky, J.; Sordillo, E.M. and Fowkes, M. (2020). Central nervous system involvement by severe acute respiratory syndrome coronavirus 2 (SARS-CoV-2). J. Med. Virol., 92(7):699-702. 
Papa, S.M.; Brundin, P.; Fung, V.S.; Kang, U.J.; Burn, D.J.; Colosimo, C.; Chiang, H.L.; Alcalay, R.N.; Trenkwalder, C. an d MDS Scientific Issues Committee (2020). Impact of the COVID-19 pandemic on Parkinson's disease and movement disorders. Mov. Disord., 35(5):711-715.

Perico, L.; Benigni, A. and Remuzzi, G. (2020). Should COVID-19 concern nephrologists? Why and to what extent? The emerging impasse of angiotensin blockade. Nephron., 144(5):213-221.

Perrin, R., Riste, L., Hann, M., Walther, A., Mukherjee, A. and Heald, A., (2020). Into the looking glass: Post-viral syndrome post COVID-19. Med. Hypotheses, 144:110-155.

Piquet, V.; Luczak, C.; Seiler, F.; Monaury, J.; Martini,A.; Ward, A.B.; Gracies, J.M.; Motavasseli, D.; Lépine, E.; Chambard, L. and Baude, M. (2021). Do patients with COVID-19 benefit from rehabilitation? Functional outcomes of the first 100 patients in a COVID-19 rehabilitation unit. Arch. Phys. Med. Rehabil., 102(6):1067-1074.

Pisano, S.; Senese, V.P.; Bravaccio, C.; Santangelo, P.; Milone,A.; Masi, G and Catone, G. (2020). Cyclothymic-hypersensitive temperament in youths: Refining the structure, the way of assessment and the clinica significance in the youth population. J. Affect. Disord., 271:272278

Raz, N. and Daugherty, A.M. (2018). Pathways to brain aging and their modifiers: free-radical-induced energetic and neural decline in senescence (FRIENDS) model-a mini-review. Gerontology, 64(1):49-57.

Reeve, A.; Simcox, E. and Turnbull, D. (2014). Ageing and Parkinson's disease: why is advancing age the biggest risk factor? Ageing Res. Rev., 14(100): 19-30.

Romero, M. and Lee, Y.S. (2007). A national portrait of chronic absenteeism in the early grades. Natl Cent Child Poverty. National Center for Children in Poverty, Columbia University.

Romero-Sánchez, C.M.; Díaz-Maroto, I.; Fernández-Díaz, E.; Sánchez-Larsen, Á.; Layos-Romero, A.; García-García, J.; González, E.; Redondo-Peñas, I.; PeronaMoratalla, A.B.; Del Valle-Pérez, J.A. and Gracia-Gil, J. (2020). Neurologic manifestations in hospitalized patients with COVID-19: The ALBACOVID registry., Neurology, 95(8):e1060-e1070.

Sadasivan, S.; Zanin, M.; O’Brien, K.; Schultz-Cherry, S. and Smeyne, R.J. (2015) Induction of microglia activation after infection with the nonneurotropic A/CA/04/2009 H1N1 influenza virus. PloS One., 10(4): e0 124047.

Saloner, B.; Parish, K.; Ward, J.A.; DiLaura, G. and Dolovich, S. (2020). COVID-19 Cases and deaths in federal and State Prisons. JAMA., 324(6):602603 .

Schirinzi, T.; Cerroni, R.; Di Lazzaro, G.; Liguori, C.; Scalise, S.; Bovenzi, R.; Conti, M.; Garasto, E.; Mercuri, N.B.; Pierantozzi, M. and Pisani, A. (2020). Selfreported needs of patients with Parkinson's disease during COVID19 emergency in Italy. Neurol. Sci., 41(6):1373-1375.

Shanbehzadeh, S.; Tavahomi, M.; Zanjari, N.; Ebrahimi-Takamjani, I. and AmiriArimi, S. (2021). Physical and mental health complications postCOVID-19: Scoping review. J. Psychosom. Res., 147:110-525.

Sher, F.; Hanif, K.; Rafey, A.; Khalid, U.; Zafar, A.; Ameen, M. and Lima, E.C. (2021). Removal of micropollutants from municipal wastewater using different types of activated carbons. J. Environ. Manage., 278:111302 .
Shigemura, J.; Ursano, R.J.; Morganstein, J.C.; Kurosawa, M. and Benedek, D.M. (2020). Public responses to the novel 2019 coronavirus (2019 $\mathrm{nCoV}$ ) in Japan: Mental health consequences and target populations. Psychiatry Clin. Neurosci., 74(4):281-282.

Sparks, K.; Cooper, C.; Fried, Y. and Shirom, A. (1997). The effects of hours of work on health: A meta-analytic review. Routledge., pp:451468.

Stoessl, A.J.; Bhatia, K.P. and Merello, M. (2020). Movement disorders in the World of COVID-19. Mov. Disord., 35(5):709-710.

Sulzer, D. (2007). Multiple hit hypotheses for dopamine neuron loss in Parkinson's disease. Trends Neurosci., 30(5):244-250.

The WHO-China Joint Mission on Coronavirus Disease 2019. (2020). World Health Organization (WHO). 1(16-24):1-40.

Tipton, P.W. and Wszolek, Z.K. (2020). What can Parkinson's disease teach us about COVID-19?. Neurol. Neurochir. Pol., 54(2):204-206.

Townsend, L.; Dyer, A.H.; Jones, K.; Dunne, J.; Mooney, A.; Gaffney, F.; O'Connor L.; Leavy, D.; O'Brien, K.; Dowds, J.; Sugrue, J.A.; Hopkins, D.; Martin-Loeches, I.; Ni Cheallaigh, C.; Nadarajan, P.; McLaughlin, A.M.; Bourke N.M.; Bergin, C.; O'Farrelly, C.; Bannan, C. and Conlon, N. (2020). Persistent fatigue following SARS-CoV-2 infection is common and independent of severity of initial infection. PLoS One., 9; 15(11):e0240784.

Twenge, J.M., Haidt, J., Joiner, T.E. and Campbell, W.K. (2020). Underestimating digital media harm. Nat. Hum. Behav., 4(4):346-348.

Wu, C.; Chen, X.; Cai, Y.; Zhou, X.; Xu, S.; Huang, H.; Zhang, L.; Zhou, X.; Du, C.; Zhang, Y. and Song, J. (2020). Risk factors associated with acute respiratory distress syndrome and death in patients with coronavirus disease 2019 pneumonia in Wuhan, China. JAMA Intern. Med., 180:934-943.

Wu, Y.M. and Kanamori, H. (2005). Rapid assessment of damage potential of earthquakes in Taiwan from the beginning of $\mathrm{P}$ waves. Bull. Seismol. Soc. Am., 95(3):118-115.

Xu, X.; Chen, P.; Wang, J.; Feng, J.; Zhou, H.; Li, X.; Zhong, W. and Hao, P. (2020) Evolution of the novel coronavirus from the ongoing Wuhan outbreak and modelling of its spike protein for risk of human transmission. Sci. China Life Sci., 63(3):457-460.

Yuan, B., Li, W., Liu, H., Cai, X., Song, S., Zhao, J., Hu, X., Li, Z., Chen, Y., Zhang, K. and Liu, Z., (2020). Correlation between immune response and self-reported depression during convalescence from COVID-19. Brain Behav. Immun., 88:39-43.

Zhang, J.J.; Dong, X.; Cao, Y.Y.; Yuan, Y.D.; Yang, Y.B.; Yan, Y.Q.; Akdis, C.A. and Gao, Y.D. (2020). Clinical characteristics of 140 patients infected with SARS-CoV-2 in Wuhan, China. Allergy., 75(7):1730-1741. doi: 10.1111/all.14238. Epub 2020 Feb 27. PMID: 32077115.

Zhang, M.W.B. and Ho, R.C. (2017). Moodle: The cost-effective solution for internet cognitive behavioral therapy (I-CBT) interventions. Technol. Healthcare, 25(1):163-165

Zhao, H.; Shen, D.; Zhou, H.; Liu, J. and Chen, S. (2020). Guillain-Barré syndrome associated with SARS-CoV-2 infection: Causality or coincidence? Lancet Neurology, 19(5):383-384. 